\title{
Feeding ecology of Hypostomus punctatus Valenciennes, 1840 (Osteichthyes, Loricariidae) in a costal stream from Southeast Brazil
}

\author{
Mazzoni, R.*, Rezende, CF. and Manna, LR. \\ Laboratório de Ecologia de Peixes, Departamento de Ecologia, \\ Universidade do Estado do Rio de Janeiro - IBRAG, \\ Rua São Francisco Xavier, 524, CEP 20550-013, Rio de Janeiro, RJ, Brazil \\ *e-mailmazzoni@uerj.br
}

Received June 25, 2009 - Accepted September 18, 2009 - Distributed August 31, 2010

(With 3 figures)

\begin{abstract}
In the present study we aimed to compare the feeding ecology of Hypostomus punctatus from a coastal stream from Southeast Brazil with data previously published for the same study site before environmental changes. Feeding preferences were assessed through a sample of 138 specimens (67 from the dry and 71 from the rainy season) using the Index of Alimentary Importance $\left(\mathrm{IA}_{\mathrm{i}}\right)$. We registered five different food items (detritus, plant fragments, Diatoms, Chloroficeae and Cianobacteries) composing the species diet. Detritus was the most abundant one both during the rainy and dry seasons $\left(\mathrm{IA}_{\text {irainny }}=90.34\right.$ and $\left.\mathrm{IA}_{\text {idry }}=96.30\right)$. No significant differences were registered for the volume of food items consumed during the rainy and dry seasons. The Frequency of Occurrence analysis showed that four (detritus, plant fragments, Diatoms and Chloroficeae) among the five all other consumed ones, were always frequent. Comparing our own results with those available for the study site, we suggest that the feeding habit of H. punctatus has changed according to environmental changes and that the species diet is strongly dependent upon environmental conditions.
\end{abstract}

Keywords: stream-dwelling fish, detritivorous, benthonic behaviour.

\section{Ecologia trófica de Hypostomus punctatus Valenciennes, 1840 (Osteichthyes, Loricariidae) de um riacho costeiro do sudeste do Brasil}

\begin{abstract}
Resumo
No presente estudo, tivemos como objetivo comparar a ecologia trófica de Hypostomus punctatus de um riacho costeiro do sudeste do Brasil com dados previamente publicados para a mesma localidade deste estudo, antes que tenha sofrido alterações ambientais. As preferências alimentares foram analisadas através da análise de 138 exemplares (67 da estação seca e 71 da estação chuvosa), utilizando-se o Índice de Importância Alimentar (IA $)$. Registramos cinco diferentes itens alimentares (detrito, fragmentos vegetais, Diatomáceas, Clorofíceas e Cianobactérias), compondo a dieta da espécie. Detrito foi o item mais abundante, tanto durante a estação chuvosa como durante a seca (IA ichuva $=90,34$ e IA $_{\text {iseca }}=96,30$ ). Não foram registradas diferenças significativas entre o volume consumido de cada um dos itens na estação seca e chuvosa. A análise da frequência de ocorrência mostrou que quatro (detrito, fragmento vegetal, Diatomáceas e Clorofíceas) entre os cinco itens consumidos foram sempre frequentes. Comparando nossos resultados com aqueles previamente publicados, sugerimos que o hábito alimentar de $H$. punctatus mudou de acordo com as alterações ambientais e que sua dieta é fortemente dependente das condições ambientais.
\end{abstract}

Palavras-chave: peixe de riacho, detritivoria, hábito bentônico.

\section{Introduction}

The Mato Grosso Stream, together with its main tributaries, Roncador, São Lourenço and "Feio" streams, composes a small fluvial system of the Brazilian East Basin in the State of Rio de Janeiro. Twenty-four species make up the Mato Grosso stream ichthyofauna and Hypostomus punctatus (Valenciennes) is one of the most abundant species (Miranda, 2009).

Hypostomus species belong to the most diverse and complex fish group among the South American catfishes

(Reis et al., 1990; Jerep et al., 2007) and are normally classified as grazer feeders, frequently inhabiting fast flowing streams in benthic areas close to rock substrate and/or submerse wood; nonetheless, they are also found in lentic environments feeding on mud and detritus (Angelescu and Gneri, 1949).

Mato Grosso stream is located in an area under extremely severe human activities following patterns found in many other Atlantic Forest fluvial systems (e.g. Mazzoni and 
Iglesias-Rios, 2007). It composes an area where conservation studies are quite recommended (Mazzoni et al., 2000; Myers et al., 2000) and trophic studies should help in the development of managing strategies (Windell and Bowen, 1978; Royce, 1996).

The present study is part of a wide research programme on the trophic ecology of stream dwelling-fishes from the East Atlantic basin and aimed to analyse the feeding ecology of $H$. punctatus from one site of Mato Grosso stream and compare it with the data obtained by Costa (1987) who worked at the same site. The results obtained would be addressed in a wide context of feeding habits associated to environmental changes.

\section{Material and Methods}

\subsection{Study area}

The Mato Grosso fluvial system belongs to the East Atlantic basin and is located in the Northeast of Rio de Janeiro State (22 ${ }^{\circ} 52^{\prime} \mathrm{S}$ and $42^{\circ} 40^{\prime} \mathrm{W}$; $22^{\circ} 53^{\prime} \mathrm{S}$ and $42^{\circ} 34^{\prime} \mathrm{W}$ ). Mato Grosso is a $2^{\text {nd }}$ order stream with its headwaters at $500 \mathrm{~m}$ asl, $11 \mathrm{~km}$ long and water discharge at Lagoa de Saquarema (Figure 1). It is a typical coastal stream with water levels solely regulated by rainfall ( 1500 mm.yr $\left.{ }^{-1}\right)$ and run-off with abundant summer (November/March) rain accentuating water fluctuations; nonetheless, tropical storms ( $>120 \mathrm{~mm}$ in a day) are very common throughout the year. Mato Grosso stream flows through meadows deforested for agricultural practises and cattle breeding and has been changing its course because of sand extraction in its lowland areas.

\subsection{Data collection and analysis}

Bimonthly samples, between March/2006 and February/2007, were done by picarés (mesh size $0.5 \mathrm{~mm}$ ) in a $100 \mathrm{~m}$ long stretch in the lowlands of Mato Grosso stream. Sample site was site II from Costa (1987) and was located in a grassland area, with gravel and sand substrata, scarce marginal aquatic vegetation and absence of canopy. Sand extraction was the most important human activity in the vicinities of the sample site.

At each sampling occasion we collected approximately 20 specimens of Hypostomus punctatus (henceforth Hypostomus). We analysed 138 Hypostomus guts being

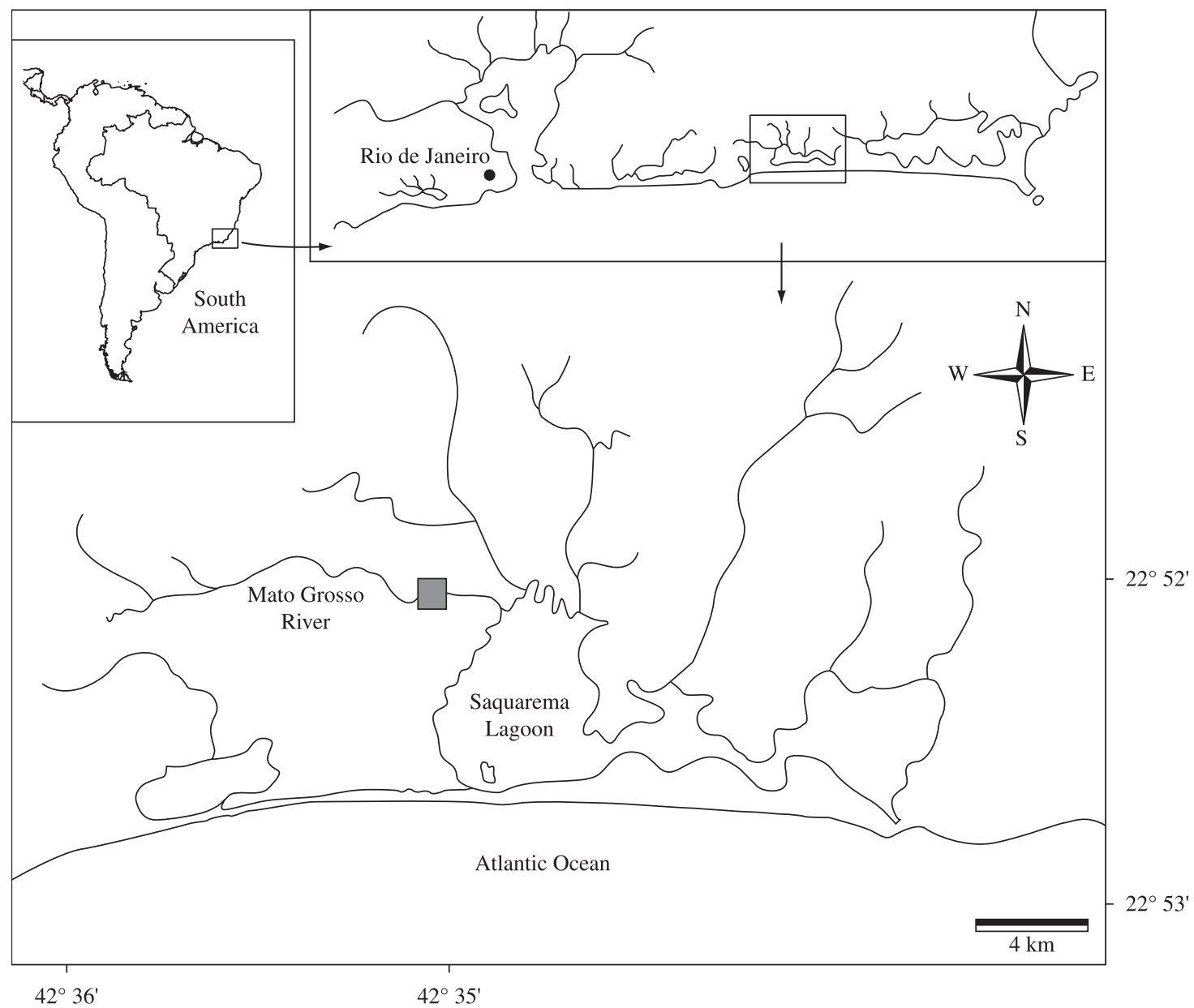

Figure 1. Mato Grosso fluvial system with indication of the sample site (grey square). This is the same site II studied by Costa (1987). 
67 from the dry and 71 from the rainy season. Voucher specimens were deposited at the Museu Nacional do Rio de Janeiro (MNRJ 29993, 30008, 30013). Sampled fishes were conditioned in ice for transportation and processed to the determination of standard length (SL, cm) and total weight (WT, gr). Gastrointestinal duct was removed through longitudinal abdominal incision, distended, measured (gut length $=\mathrm{GL} ; \mathrm{cm}$ ) and their first $1 / 3$ portion was fixed in formalin $(5 \%)$ and kept in alcohol solution $\left(70^{\circ} \mathrm{GL}\right)$ for posterior analysis.

Gut content was diluted in alcohol solution and analysed in a Sedgewick-Rafter counting camera (SRcc) under an optical microscope. Diet items were identified according to the literature (Bicudo, CEM. and Bicudo, RMT., 1970) to the lowest feasible taxonomical level and quantified according to Aranha (1993). The number of fields to be analysed in the SRcc was determined through the collecting curve, based on the analysis of 8 intestines, 4 from the dry season and 4 from the wet season, considering each food categories registered in the guts. Intestinal content was quantified through the Volumetric $\left(V_{\mathrm{o}}\right)$ and Frequency of Occurrence $\left(F_{\mathrm{O}}\right)$ methods (Hyslop, 1980).

Data of each sample occasion was grouped according to seasonal characteristics of rainfall following data available in the $6^{\circ}$ Distrito do Instituto Nacional de Meteorologia (INMET), thus temporal analysis was done considering the dry $\left(<100 \mathrm{~mm}^{3}\right.$.month ${ }^{-1}-$ April to September $)$ and rainy (>100 $\mathrm{mm}^{3} \cdot$ month $^{-1}-$ October to March) seasons (Figure 2).

The temporal (rainy versus dry season) variation of diet was analysed through the Index of Alimentary Importance $\left(\mathrm{IA}_{\mathrm{i}}\right)$. The $\mathrm{IA}_{\mathrm{i}}$ consisted in the correlation between $\mathrm{F}_{\mathrm{O}}$ and $\mathrm{V}_{\mathrm{O}}$ data as proposed by Kawakami and Vazzoler (1980) and adapted by Hahn et al. (1997). The $\mathrm{IA}_{\mathrm{i}}$ was applied according to the following model: $\left.\mathrm{IA}_{\mathrm{i}}=\left(\mathrm{F}_{\mathrm{i}} * \mathrm{~V}_{\mathrm{i}}\right) / \sum \mathrm{F}_{\mathrm{i}} * \mathrm{~V}_{\mathrm{i}}\right) * 100$, where $\mathrm{i}=1,2, \ldots . \mathrm{n}$ food itens; $\mathrm{F}_{\mathrm{i}}=$ frequency of occurrence of a given food item; $V_{i}=$ volume of a given food item. Mean values of $\mathrm{V}_{\mathrm{O}}$ data were used in the seasonal diet analysis (rainy versus dry season) and their differences were tested through the Kolmogorov-Smirnoff test (KS).

\section{Results}

According to the collecting curves (Figure 3) we detected that the cumulative frequency of items composing Hypostomus diet was stabilised, in five items, at 27 and 26 SRcc fields for the dry and rainy seasons, respectively. Nonetheless, considering the high variation for the numbers of SRcc fields needed for the collecting curve stabilisation, and to be safe about the diet determination, we decided to analyse 40 SRcc fields of each intestine sample.

Data analysis showed that five different items were consumed by the species. Within these items detritus were the most abundant one, both during the rainy and dry seasons (Table 1). No significant differences $\left(\mathrm{KS}-\mathrm{x}^{2}=4.08, \mathrm{gl}=2 ; \mathrm{p}>0.05\right)$ were registered for the volume of food items consumed during the rainy and dry seasons, although plant fragments tended to be more abundant during the rainy season (Table 1).

Although the $\mathrm{IA}_{\mathrm{i}}$ of detritus in the Hypostomus diet was high, the frequency of occurrence analysis showed that four (detritus, plant fragments, Diatoms and Chloroficeae), among the five all other consumed food items, were always frequent (Table 1). These items were constant throughout the study period and showed high $\mathrm{F}_{\mathrm{O}}$ but low $\mathrm{V}_{\mathrm{O}}$, both during the dry and rainy season. The percentage of consumed items did not vary between the dry and rainy season, thus, diet did not vary seasonally.

\section{Discussion}

According to Agostinho et al. (1997) and Hahn et al. (1997), detritivory is a frequent feeding habit among Loricariidae species and has been considered as a specialised behaviour related to the morphological adaptation of the digestive system (mouth shape and position and intestine length). Such morphological design allowed the Loricariidae species to inhabit and explore benthonic microhabitats grazing on algae and associated microfauna (Garavello, JC. and Garavello, JP., 2004).

Many different feeding habits have been described for the Loricariidae species. Dias Jr. et al. (1984), Albrecht and Silveira (2001), Castro and Caramaschi (2003) and Gomiero and Braga (2005) classified Hypostomus species as illiophagous because of the low frequency of algae items and the high incidence of detritus registered in their studied species. Menezes (1949) and Nomura et al. (1975) described their Loricariidae species as herbivorous following the high incidence of plant matter found in their diet. Delariva and Agostinho (2001) studied six Loricariidae species and found that they have extreme variable diet moving across herbivory, iliophagy and omnivory. These findings reflect the behavioural plasticity recurrently mentioned for Hypostomus species (e.g. Buck and Sazima, 1995; Casati et al., 2005).

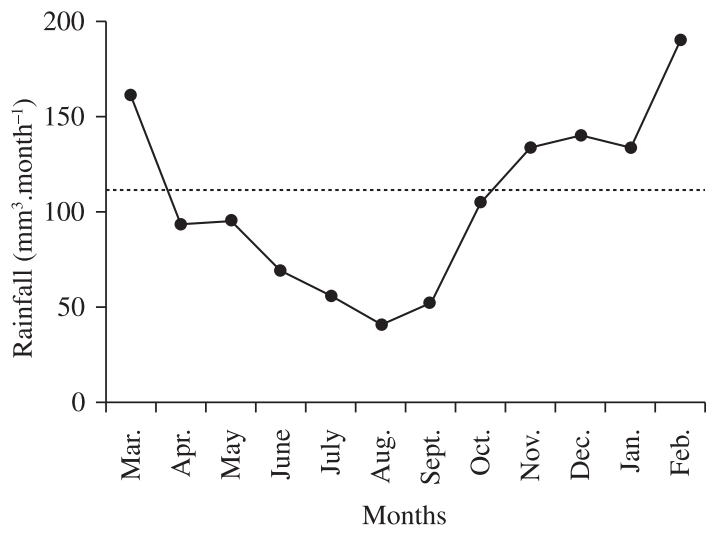

Figure 2. Temporal variation of pluviometric indices based in the total rain $\left(\mathrm{mm}^{3}\right)$ of each month from March/2006 to February/2007. Data were based on the information available at $6^{\circ}$ Distrito do Instituto Nacional de Meteorologia (INMET). 

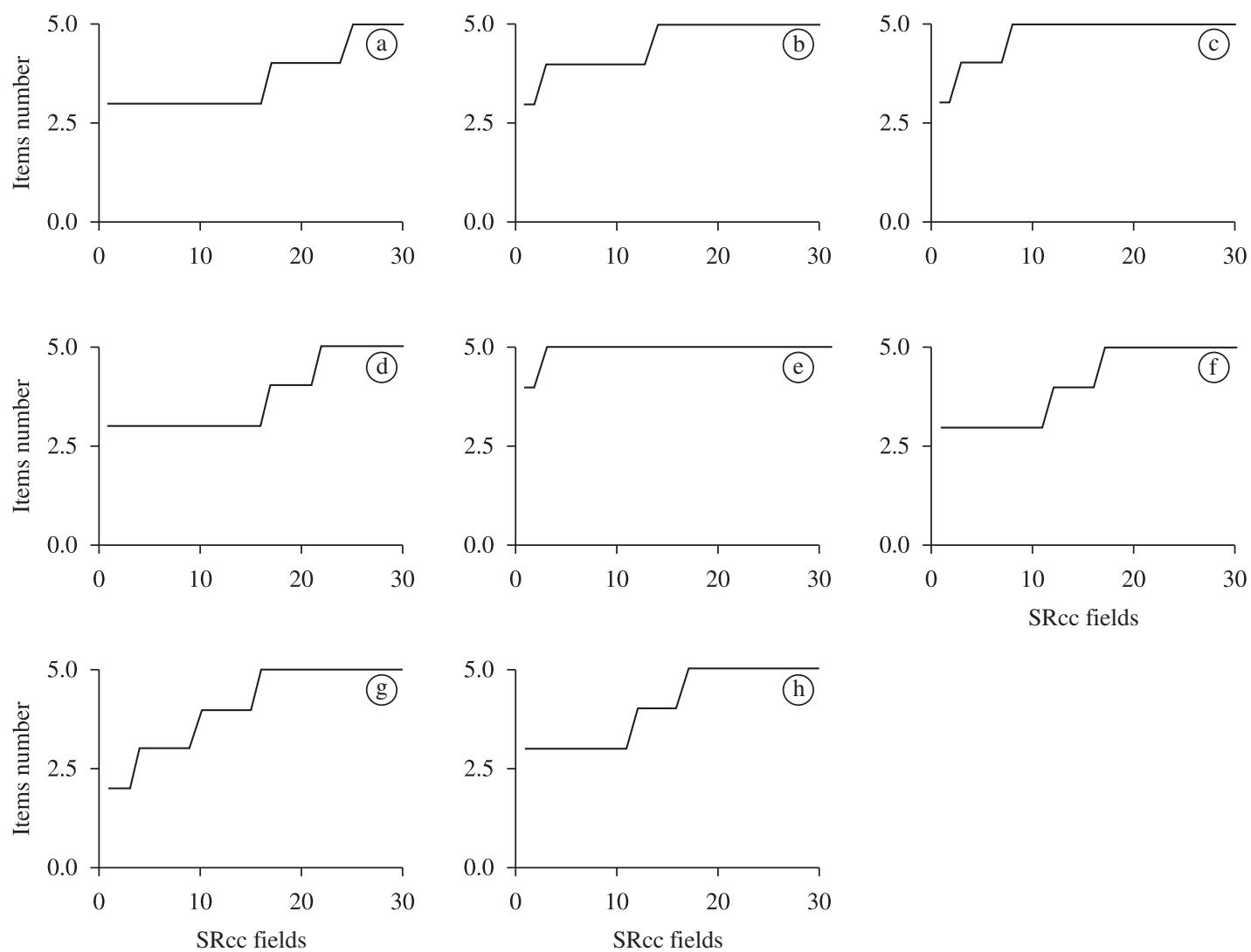

Figure 3. Collecting curves based in the number of Sedgewick-Rafter counting camera (SRcc) fields needed to the stabilization of the number of food item registered in the diet of Hypostomus punctatus. Curves were based in four intestines from the rainy ( $a, b, c$ and d) and dry (e, f, g and h) seasons.

Table 1. Volumetric $\left(V_{\mathrm{o}}\right)$ and Frequency of Occurrence $\left(F_{\mathrm{o}}\right)$ data obtained for each food item registered for Hypostomus punctatus from Mato Grosso Stream, Saquarema during the dry and rainy seasons.

\begin{tabular}{lrrrrrrr}
\hline \multirow{2}{*}{ Itens } & \multicolumn{3}{c}{ Dry season } & & \multicolumn{3}{c}{ Rainy season } \\
\cline { 2 - 3 } \cline { 6 - 8 } & $\mathbf{V}_{0}$ & \multicolumn{1}{c}{$\mathbf{F}_{0}$} & $\mathbf{I A}_{i}$ & & $\mathbf{V}_{0}$ & $\mathbf{F}_{0}$ & $\mathbf{I A}_{i}$ \\
\hline Detritus & 42.16 & 100.00 & 96.30 & & 36.83 & 100.00 & 90.34 \\
Plant Fragment & 0.89 & 75.86 & 1.54 & & 2.37 & 85.00 & 4.94 \\
Diatomaceae algae & 0.86 & 100.00 & 1.96 & & 2.01 & 94.05 & 4.64 \\
Filamentous algae & 0.22 & 37.93 & 0.19 & & 0.12 & 21.01 & 0.06 \\
Cianobacteries & 0.001 & 3.44 & 0.001 & & 0.01 & 3.22 & 0.001 \\
\hline
\end{tabular}

Hypostomus from Mato Grosso stream fed mainly on detritus following the results found by Albrecht and Silveira (2001), Castro and Caramaschi (2003) and Gomiero and Braga (2005). Nonetheless, such results differ from those found by Casatti (2002) while working in a similar stream and found that the Hypostomus species fed mainly on periphyton.

The importance of the surrounding landscape in the diet of fish species has been recognised (Vitule et al., 2003) and it has been frequently mentioned that environmental conditions are very important to the Loricariidae species as their diet is strongly associated to the substrate and the amount of available organic matter/detritus (Casatti et al., 2005; Cardone et al., 2006). Thus, diet modification of Loricariidae species was frequently associated to altered environments as a consequence of differences in the formation of periphyton and organic matter deposition (e.g. Angelescu and Gneri, 1949; Dias Jr. et al., 1984; Cardone et al., 2006).

Ferreira and Casatti (2006) found that detritus was the main feeding item in the diet of 3 Hypostomus species inhabiting a $1^{\text {st }}$ order stream located in a grassland area. The present work was developed in a grassland area and our results corroborate those found by Ferreira and Casatti (2006). Nonetheless, Costa (1987) studied the same species 
at the same site in Mato Grosso stream and found very different results, with algae prevailing in the diet. Algivory has been widely observed among Hypostomus species and largely dependent on pristine conditions (Beamish et al., 2006; Buck and Sazima, 1995). Indeed, the study site landscape has changed a lot since that time. Costa (1987) described the area as composed of marsh vegetation with predominant Gramineae and Typhaceae and sand and gravel substrata. Our study site was exactly the same studied by Costa (1987), but nowadays strong environmental changes have improved in the area, and the surrounding landscape and stream substrata has changed a lot with the important presence of a sand and mud substrata and little incidence of marginal vegetation (Miranda, 2009). The main cause of such changes was the sand extraction causing important siltation on stream banks and changes in resource availability to the fish fauna. This scenario responds to the dynamic of fish feeding habits and could explain the differences between Costa's and our own results.

Acknowledgements - We thank the members of the Laboratório de Ecologia de Peixes from the Universidade do Estado do Rio de Janeiro for helping in the field work. Ricardo Iglesias Rios for the valuable comments on an earlier draft of the manuscript and to Chiara Mazzoni for the English revision. This work is part of the Scientific Initiation study of LRM (PIBIC/FAPERJ / E-26/152.830/2005) and was financed by a grant from FAPERJ / APQ1 / E-26/171.555-00.

\section{References}

AGOSTINHO, AA., HAHN, NS., GOMES, LC. and BINI, LM., 1997. Estrutura trófica. In VAZZOLER, AEAM., AGOSTINHO, AA. and HAHN, NS. (Eds.). A planície de inundação do alto Rio Paraná: aspectos físicos, biológicos e socioeconômicos. Maringá: Eduem/Nupelia.

ALBRECHT, MP. and SILVEIRA, CM., 2001. Alimentação de Loricariichthys anus (Teleostei; Loricariidae) nas lagoas Marcelino e Peixoto, Planície Costeira do Rio Grande do Sul. Acta Limnologica Brasiliensia, vol. 13, no. 1, p. 79-85.

ANGELESCU, V. and GNERI, FS., 1949. Adaptaciones del aparato digestivo al regimen alimentício em algunos peces del Rio Uruguay del Rio de la Plata. Revista del Instituto Nacional de Investigacion de las Ciências Naturales, vol. 1, no. 2, p. 159-272.

ARANHA, JMR., 1993. Método para análise quantitativa de algas e outros itens microscópicos de alimentação de peixes. Acta Biológica Paranaense, vol. 22, no. 1, p. 71-76.

BEAMISH, F., SA-ARDRIT, P. and TONGNUNUI, S., 2006. Habitat characteristics of the Cyprinidae in small rivers in central Thailand. Environmental Biology of Fishes, vol. 76, no. 2-4, p. $237-253$.

BICUDO, CEM. and BICUDO, RMT., 1970. Algas de águas continentais brasileira: chave ilustrada para identificação de gêneros. São Paulo: FBDEC. 228 p.

BUCK, S. and SAZIMA, I., 1995. An assemblage of mailed catfishes in Southeastern Brazil: distribuition, activity, and feeding. Ichthyological Exploration of Freshwaters, vol. 6, no. 4, p. 325-332.
CARDONE, IB., LIMA-JUNIOR, SE. and GOITEIN, R., 2006. Diet and capture of Hypostomus strigaticeps (Siluriformes, Loricariidae) in a small brazilian stream: relationship with limnological aspects. Brazilian Journal of Biology, vol. 66, no. 1a, p. 25-33.

CASATTI, L., 2002. Alimentação dos peixes em um riacho do Parque Estadual Morro do Diabo, Bacia do Alto Rio Paraná, Sudeste do Brasil. Biota Neotropica, 2:BN02502022002.

CASATTI, L., ROCHA, FC. and PEREIRA, DC., 2005. Habitat use by two species of Hypostomus (Pisces, Loricariidae) in Southeastern Brazilian streams. Biota Neotropica, vol. 5, no. 2, p. 1-9.

CASTRO, ALM. and CARAMASHI, EP., 2003. Alimentação de Hypostomus emarginatus (Teleostei, Loricariidae) no Alto Rio Tocantis antes e após o represamento pela UHE Serra da Mesa, GO. Biociências, vol. 11, no. 1, p. 23-30.

COSTA, WJEM., 1987. Feeding habits of a fish community in a tropical coastal stream, Rio Mato Grosso, Brazil. Studies on Neotropical Fauna and Environment, vol. 22, no. 2, p. $145-153$.

DELARIVA, RL. and AGOSTINHO, AA., 2001. Relationship between morphology and diets of six neotropical loricariids. Journal of Fish Biology, vol. 58, no. 4, p. 832-847.

DIAS, Jr., C., OSHIRO, LMY. and MAZZONI, R., 1984. Alimentação do cascudo, Hypostomus sp. (Osteichthyes, Loricariidae) no lago Açu da Universidade Federal do Rio de Janeiro. Anais do III Simpósio Brasileiro de Aquicultura, vol. 1, p. 245-255.

FERREIRA, CP. and CASATTI, L., 2006. Integridade biótica de um córrego na bacia do Alto Rio Paraná avaliada por meio da comunidade de peixes. Biota Neotropica, 6:BN00306032006.

GARAVELLO, JC. and GARAVELLO, JP., 2004. Spatial distribution and interaction of four species of the catfish genus Hypostomus Lacépède with bottom of Rio São Francisco, Canindé do São Francisco, Sergipe, Brazil (Pisces, Loricariidae, Hypostominae). Brazilian Journal of Biology, vol. 64, no. 3b, p. $591-598$.

GOMIERO, LM. and BRAGA, FMS., 2005. Uso do grau de preferência alimentar para a caracterização da alimentação de peixes na APA de São Pedro e Analândia. Acta Scientiarum Biological Sciences, vol. 27, no. 3, p. 265-270.

HAHN, NS., FUGI, R., ALMEIDA, VLL., RUSSO, MR. and LOUREIRO, VE., 1997. Dieta e atividade alimentar de peixes do reservatório de Segredo. In AGOSTINHO, AA. and GOMES, LC. (Eds.). Reservatório de Segredo - bases ecológicas para o manejo. Maringá: Eduem/Nupelia. 387 p.

HYSLOP, EJ., 1980. Stomach contents analysis - a review of methods and their application. Journal of Fish Biology, vol. 17, no. 4, p. 411-429.

JEREP, FC., SHIBATTA, OA. and ZAWADZKI, CH., 2007. A new species of Hypostomus Lacépède, 1803 (Siluriformes: Loricariidae) from the upper river Paraná basin, Southern Brazil. Neotropical Ichthyology, vol. 5, no. 4, p. 435-442.

MAZZONI, R., FIGUEIREDO, CA., BIZERRIL, CRF., NUNAN, GW., TANIZAKI, K., MENEZES, NA., CAETANO, OM., and BUCKUP, PA., 2000. Peixes. In BERGALLO, HG., ROCHA, CFD., van SLUYS, M. and ALVES, MAS. (Orgs). A Fauna Ameaçada de Extinção do Rio de Janeiro. Rio de Janeiro: EDUERJ. $166 \mathrm{p}$. 
MAZZONI, R. and IGLESIAS-RIOS, R., 2007. Patterns of investment of the reproductive strategy of two stream-dwelling Characidae. Brazilian Journal of Biology, vol. 67, no. 4, p. 695-699.

MENEZES, RS., 1949. Alimentação do carí chicote, Loricaria typus Bleeker, da Bacia do Rio Parnaíba, Piauí (Actinopterygii, Loricariidae, Loricariinae). Revista Brasileira de Biologia = Brazilian Journal of Biology, vol. 9, no. 3, p. 479-484.

MIRANDA, JC., 2009, Ecologia e padrões ecomorfológicos em comunidades de peixes do sistema fluvial do rio Mato Grosso, Saquarema, RJ. Rio de Janeiro: Programa de Pós-Graduação em Biologia/Ecologia, UERJ. (Tese de Doutorado)

MYERS, N., MITTERMEIER, RA., MITTERMEIER, CG., FONSECA, GA. and KENT, J., 2000. Biodiversity hotspots for conservation priorities. Nature, vol. 403, p. 853-858.

NOMURA, H., OLIVIERI, MJ., LELLIS, AMP. and CALDO, BE., 1975. Caracteres merísticos e biologia do cascudo-bugio,
Plecostomus ancistroides Ihering, 1911 (Pisces, Loricariidae). Científica, vol. 3, p. 232-245.

REIS, RE., WEBER, C. and MALABARBA, LR., 1990. Review of the genus Hypostomus Lacépède, 1803 from Southern Brazil, with descriptions of three new species (Pisces, Siluriformes, Loricariidae). Revue Suisse de Zoologie, vol. 97, no. 3, p. 729-766.

ROYCE, HF., 1996. Introduction to the practice of fishery science. California: Academic Press. 428 p.

VITULE, RS., BRAGA, MR. and ARANHA, JMR., 2008. Ontogenetic, spatial and temporal variations in the feeding ecology of Deuterodon langei Travassos, 1957 (Teleostei: Characidae) in a Neotropical stream from Atlantic rainforest, southern Brazil. Neotropical Ichthyology, vol. 6, no. 2, p. 211-222.

WINDELL, JT. and BOWEN, SH., 1978. Methods for study of fish diets based on analysis of stomach contents. In BAGENAL, T. (Ed.). Methods for assessment of fish production in fresh waters. $3^{\text {rd }}$ ed. Oxford: Blackwell Scientific. 